\title{
Uridine Metabolism in the Goldfish Retina During Optic Nerve Regeneration: Cell-Free Preparations
}

\author{
Shinichi Kohsaka, Linda A. Dokas, and Bernard W. Agranoff \\ Neuroscience Laboratory, Mental Health Research Institute and Department of Biological Chemistry, \\ The University of Michigan, Ann Arbor, Michigan, U.S.A.
}

\begin{abstract}
The activities of uridine kinase (EC 2.7.1.48), uridine monophosphate (UMP) kinase (EC 2.7.1.3.14), and uridine diphosphate (UDP) kinase (EC 2.7.4.6) were measured in retinal high-speed supernatant fractions following unilateral optic nerve crush in the goldfish. The enzyme activities followed a similar time course, with initial increases $2-3$ days following nerve crush, peak activity at 4 days, and a gradual return to basal levels by day 21. The magnitude of the stimulation on day 4 was about $35 \%$ in each case. Activities of two enzymes of intermediary metabolism, pyruvate kinase (EC 2.7.1.40) and lactic dehydrogenase (EC 1.1.1.27), were not altered, indicating that the coordinate increases in nucleoside and nucleotide kinase activities were specific responses to the nerve injury. The increased labeling could not be explained by altered phosphohydrolytic activities. The nature of the enhancement was further studied in UDP kinase, the most active of the kinases examined. Neither low-molecular-weight components nor substrate availability could account for the observed increase in UDP kinase in the 4 day post-crush retinas. The $K_{\mathrm{m}}$ for UDP was unaltered, and a mixing experiment did not support the possibility that stimulatory or inhibitory factors played a role. The enhancement of UDP kinase activity was blocked by injection of actinomycin $D$ following nerve crush. The results suggest that the observed increases in enzymes of uridine metabolism result from their increased formation following nerve crush. Key Words: Uridine-Goldfish retina-Regeneration-Nucleoside kinase-Nucleotide kinase. Kohsaka S. et al. Uridine metabolism in the goldfish retina during optic nerve regeneration: Cell-free preparations. J. Neurochem. 36, 1166-1174 (1981).
\end{abstract}

Following crush of the goldfish optic nerve, a series of morphological and biochemical events ensues that has been correlated with the eventual regeneration of the nerve and recovery of function (for review, see Cragg, 1970; Grafstein and McQuarrie, 1978).

Involvement of RNA in these events is inferred from nucleolar prominence and cytoplasmic basophilia seen in retinal ganglion cells (Murray and Grafstein, 1969), from the autoradiographic distribution of silver grains over regenerating retinal cells following intraocular injection of $\left[{ }^{3} \mathrm{H}\right]$ uridine (Murray, 1973), and from increased axonal transport of RNA-like substances in the newly regenerated goldfish optic nerve (Ingoglia, 1978).

An increase in RNA labeling as well as in precursor utilization by incubated retinas has been correlated with increased labeling of poly(A)-containing RNA (Burrell et al., 1978), increased mRNA for tubulin (Burrell et al., 1979), and with increased tubulin labeling (Heacock and Agranoff, 1976; Giulian et al., 1980).
Received August 27, 1980; accepted October 6, 1980.

Address correspondence and reprint requests to Dr. Bernard W. Agranoff, Neuroscience Laboratory Building, University of Michigan, 1103 E. Huron, Ann Arbor, Michigan 48109.

The present address of Linda A. Dokas is Department of Biochemistry, Medical College of Ohio, Toledo, Ohio 43699.

Abbreviations used: HEPES, $\mathrm{N}-2$-Hydroxyethylpiperazine-
$N^{\prime}$-2-ethanesulfonic acid; HVE, High voltage electrophoresis; LDH, Lactic dehydrogenase; $\mathbf{N}$, Normal; NDP, Nucleoside diphosphate; PC, Post-crush; PGA, 3-Phospho-D-glyceric acid; PK, Pyruvate kinase; PRPP, Pyrophosphoryl-ribose phosphate; TCA, Trichloroacetic acid; TRH, Thyrotropin-releasing hormone; UDPG, Uridine 5'-diphosphate glucose. 
We recently proposed that an observed enhanced uptake of $\left[{ }^{3} \mathrm{H}\right]$ uridine into the post-crush $(\mathrm{PC})$ retina resulted from increased rates of its phosphorylation (Dokas et al., 1981). In the present study, we provide details of the nature of the enhanced rate of utilization of uridine in the retina during optic nerve regeneration gained from studies in cell-free preparations.

\section{MATERIALS AND METHODS}

\section{Materials}

$\left[5,6-{ }^{3} \mathrm{H}\right]$ uridine $(36.8 \mathrm{Ci} / \mathrm{mmol})$ was obtained from New England Nuclear Corporation (Boston, Massachusetts). $\left[5-{ }^{3} \mathrm{H}\right]$ Uridine $5^{\prime}$-monophosphate $(11.2 \mathrm{Ci} / \mathrm{mmol})$ and [5-3 $\left.{ }^{3} \mathrm{H}\right]$ uridine 5 '-diphosphate $(12.7 \mathrm{Ci} / \mathrm{mmol})$ were obtained from Amersham Corporation (Arlington Heights, IIlinois). Unlabeled substrates, UDPG, dithiothreitol, bovine testis hyaluronidase, and rabbit muscle $\mathrm{LDH}$ were purchased from Sigma Chemical Company (St. Louis, Missouri).

\section{Animals}

Goldfish (Carrasius auratus) 6-7 cm in body length obtained from Ozark Fisheries (Stoutland, Missouri), were anesthetized with tricaine methane sulfonate (Ayerst Laboratories, New York, New York), and intraorbital crush of the right optic nerve was performed as previously described (Heacock and Agranoff, 1976). The left optic nerve remained intact so that the left retina served as a control. In some fish, actinomycin D was injected intraocularly in a $5 \mu \mathrm{l}$ vol. by means of a 30-gauge needle inserted through the sclera at the margin of the iris. Fish were stored at $20-22^{\circ} \mathrm{C}$.

\section{Preparation of Retinal High-Speed Supernatant Fractions}

At various times following axotomy, both $\mathrm{PC}$ and the contralateral control (normal, $\mathbf{N}$ ) retinas were removed. Retinas were treated with hyaluronidase $(0.4 \mathrm{mg} / \mathrm{ml})$ in a HEPES-salts-glucose medium (Dunlop et al., 1974) at $25^{\circ} \mathrm{C}$ for $20 \mathrm{~min}$ to remove adhering vitreous. This treatment with hyaluronidase was found not to affect subsequent measurements of nucleoside and nucleotide kinase activities. Five to 25 rinsed pooled $\mathrm{PC}$ or $\mathrm{N}$ retinas were then homogenized in $1-5 \mathrm{ml}$ of $10 \mathrm{~mm}-\mathrm{Tris}-\mathrm{HCl}$ buffer ( $\mathrm{pH} 7.4$ ) containing $10 \mathrm{mM}-\mathrm{KCl}, 2 \mathrm{mM}-\mathrm{MgCl}_{2}$, and $1 \mathrm{mM}$-dithiothreitol, and centrifuged at $100,000 \times \mathrm{g}$ for $60 \mathrm{~min}$. The resulting high-speed supernatant fractions were subjected to nucleoside and nucleotide kinase assays. In additional experiments, aliquots of PC and $\mathrm{N}$ retinal high-speed supernatant fractions were first dialyzed overnight against the homogenization buffer.

\section{Enzyme Assays of Nucleoside and Nucleotide Kinases}

An aliquot of retinal high-speed supernatant fractions was preincubated at $25^{\circ} \mathrm{C}$ for $5 \mathrm{~min}$ in $400 \mu$ l of medium containing $50 \mathrm{~mm}$-HEPES $(\mathrm{pH} 7.4), 0.2 \mathrm{~mm}-\mathrm{ATP}, 5$ $\mathrm{mM}-\mathrm{MgSO}_{4}$, and $0.5 \mathrm{~mm}-3$-phospho-D-glyceric acid (PGA). Thereafter, the reaction was initiated by the addition of $2.86 \mu \mathrm{Ci}$ of $\left[{ }^{3} \mathrm{H}\right]$ uridine $\left(2 \times 10^{-7} \mathrm{M}\right.$ final concentration), $1.0 \mu \mathrm{Ci}$ of $\left[{ }^{3} \mathrm{H}\right]$ UMP $\left(10^{-4} \mathrm{M}\right)$, or $1.0 \mu \mathrm{Ci}$ of $\left[{ }^{3} \mathrm{H}\right] \mathrm{UDP}\left(10^{-3} \mathrm{M}\right)$. After $5 \mathrm{~min}$, reactions were terminated by the addition of $2 \mathrm{ml}$ of $10 \%$ trichloroacetic acid (TCA). After being mixed well, samples were centrifuged at 800 $\times g$ for $10 \mathrm{~min}$ and the resultant supernatant fractions were washed three times with the same volume of ether and then lyophilized. Residues were redissolved in $100-200 \mu \mathrm{l}$ of water and a portion of each sample was applied to premoistened Whatman No. 1 paper with 200 $\mu \mathrm{g}$ each of unlabeled uridine, UMP, UDP, UTP, and UDPG as carriers, and high voltage electrophoresis (HVE) was carried out in $60 \mathrm{~mm}$-sodium oxalate buffer, pH 1.5 , for $30 \mathrm{~min}$ at $4000 \mathrm{~V}$ or in pyridine acetate buffer, pH 4.3 (pyridine-acetic acid-water; 14:40:356) for $45 \mathrm{~min}$ at $4500 \mathrm{~V}$ as previously described (Dokas et al., 1981). Separated nucleotides were visualized following an ammonium molybdate spray and ultraviolet (UV) radiation (Bandurski and Axelrod, 1951). An appropriate region was cut out and oxidized in a Tricarb Oxidizer (Packard, Model 306), or eluted in $1 \mathrm{ml}$ of water and counted for radioactivity in Monophase-40 scintillant (Packard Instruments, Downers Grove, Illinois). Protein content was determined by the method of Lowry et al. (1951).

\section{Lactic Dehydrogenase and Pyruvate Kinase Assay}

Retinas were homogenized in $50 \mathrm{~mm}$-Tris- $\mathrm{HCl}$ buffer (pH 7.4) and centrifuged for $20 \mathrm{~min}$ at $30,000 \times \mathrm{g}$. The activities of lactic dehydrogenase (LDH) and pyruvate kinase (PK) were assayed in the supernatant fractions according to the methods of Wroblewski and LaDue (1955) and Nicholas and Bachelard (1974), respectively.

\section{RESULTS}

\section{Formation of Labeled Uridine Nucleotides in High-Speed Supernatant Fractions of Normal Retina}

Figure 1 shows the distribution of labeled nucleotides formed from $\left[{ }^{3} \mathrm{H}\right]$ uridine, $\left[{ }^{3} \mathrm{H}\right] \mathrm{UMP}$, and [ $\left.{ }^{3} \mathrm{H}\right]$ UDP and ATP in high-speed supernatant fractions of normal retina. When $\left[{ }^{3} \mathrm{H}\right]$ uridine was used as a substrate, the only labeled uridine nucleotide that accumulated in measurable amounts was UTP. No detectable radioactivity co-migrated with UMP, UDP, or UDPG. The rate of UTP formation from [ ${ }^{3} \mathrm{H}$ ] uridine was $0.51 \mathrm{pmol} / \mathrm{mg}$ protein $/ \mathrm{min}$ (Table 1). When $\left[{ }^{3} \mathrm{H}\right] \mathrm{UMP}$ was the substrate, measurable amounts of radioactivity were detected co-migrating with UDPG, UDP, and UTP (about 1\%, 14\%, and $85 \%$, respectively), but not with uridine (Fig. 1). The rate of UTP formation from $\left[{ }^{3} \mathrm{H}\right]$ UMP was $11.0 \mathrm{nmol} / \mathrm{mg}$ protein $/ \mathrm{min}$ (Table 1). When $\left[{ }^{3} \mathrm{H}\right.$ ]UDP was used as a substrate, over $99 \%$ of the recovered product was UTP, and the remainder co-migrated with UDPG (Fig. 1). The rate of UTP 


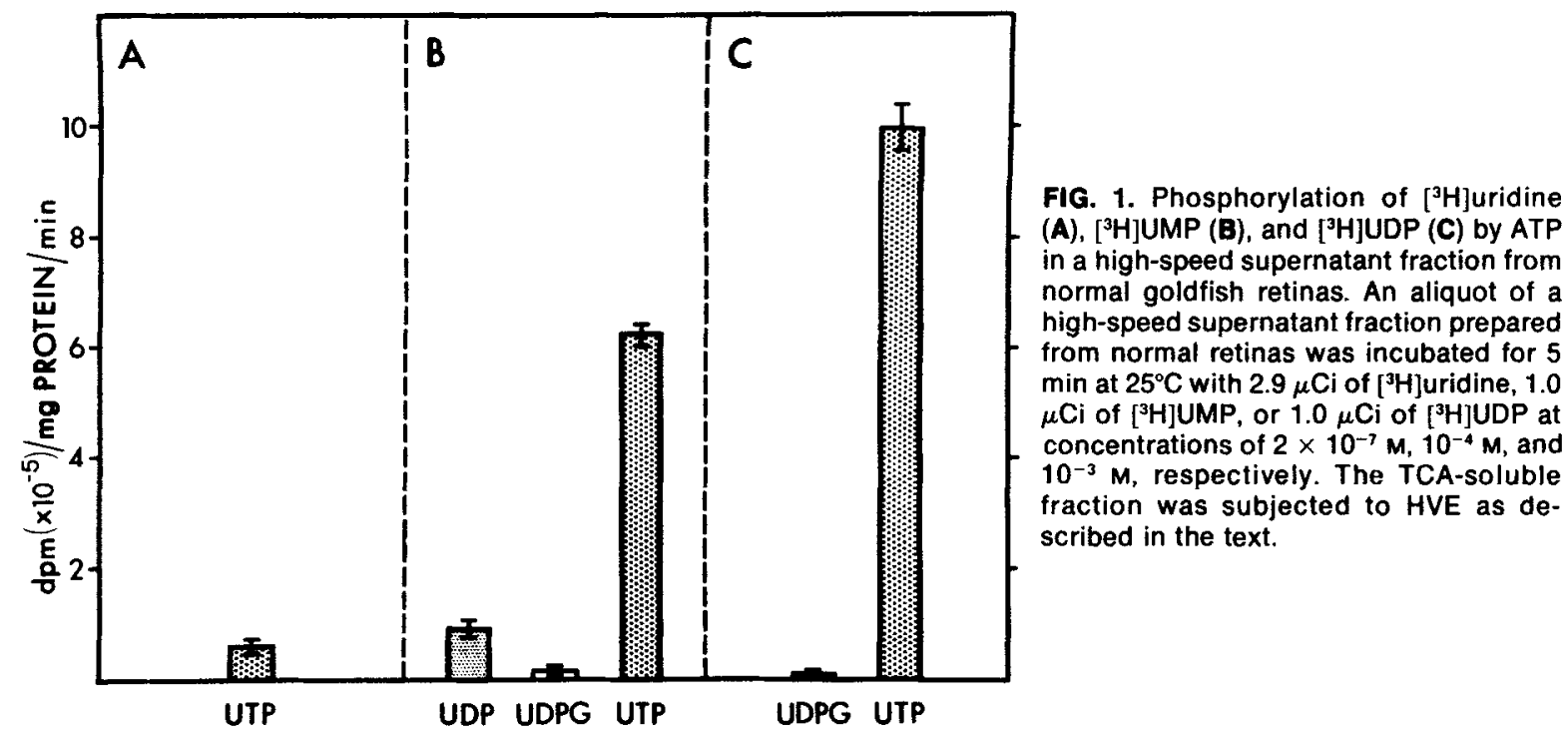

formation from $\left[{ }^{3} \mathrm{H}\right]$ UDP was $202 \mathrm{nmol} / \mathrm{mg}$ protein/min (Table 1). The results demonstrated that a retinal high-speed supernatant fraction phosphorylated uridine and its nucleotides and, further, that there were no apparent hydrolytic activities. The stated reaction rates show that the rate-limiting step of uridine metabolism in the assay system employed involves uridine kinase. With UMP as substrate, the rate-limiting step involves UMP kinase. The rate of UTP labeling from $\left[{ }^{3} \mathrm{H}\right]$ uridine, $\left[{ }^{3} \mathrm{H}\right] \mathrm{UMP}$, and $\left[{ }^{3} \mathrm{H}\right] \mathrm{UDP}$ therefore expresses approximately the activities of uridine kinase, UMP kinase, and UDP kinase, respectively.

\section{Changes in Uridine Kinase, UMP Kinase, and UDP Kinase Activities in the Retina Following Optic Nerve Crush}

Since results of incubations of whole retina with $\left[{ }^{3} \mathrm{H}\right]$ uridine and $\left[{ }^{3} \mathrm{H}\right]-5^{\prime}$-deoxyadenosine (Dokas et al., 1981) suggest that nucleoside phosphorylation

TABLE 1. The rate of utilization of $\left[{ }^{3} \mathrm{H}\right]$ uridine, $\left.{ }^{3} \mathrm{H}\right] U M P$, and $\left[{ }^{3} \mathrm{H}\right] U D P$ by retinal high-speed supernatants

\begin{tabular}{ccc}
\hline Labeled substrate & Rate of UTP formation & $\mathrm{N}$ \\
\hline Uridine & $0.51 \pm 0.02 \mathrm{pmol} / \mathrm{mg}$ protein $/ \mathrm{min}$ & 15 \\
UMP & $11.0 \pm 0.3 \mathrm{nmol} / \mathrm{mg}$ protein $/ \mathrm{min}$ & 16 \\
UDP & $203 \pm 4 \quad \mathrm{nmol} / \mathrm{mg}$ protein $/ \mathrm{min}$ & 16 \\
\hline
\end{tabular}

Retinal high-speed supernatant fractions were incubated with $2.9 \mu \mathrm{Ci}$ of $\left[{ }^{3} \mathrm{H}\right]$ uridine, $1.0 \mu \mathrm{Ci}$ of $\left[{ }^{3} \mathrm{H}\right] \mathrm{UMP}$, or $1.0 \mu \mathrm{Ci}$ of $\left[{ }^{3} \mathrm{H}\right]$ UDP as described in Materials and Methods. Rates of UTP labeling were measured following separation of labeled uridine nucleoside and nucleotides by HVE. Values are the mean \pm S.E.M. of the indicated number of individual experiments. rather than uptake is enhanced in the goldfish retina following optic nerve crush, we examined uridine kinase, UMP kinase, and UDP kinase activities by measuring UTP formation in $\mathrm{N}$ and PC retinal high-speed supernatant fractions, using $\left[{ }^{3} \mathrm{H}\right]$ uridine, $\left[{ }^{3} \mathrm{H}\right] \mathrm{UMP}$, and $\left[{ }^{3} \mathrm{H}\right] \mathrm{UDP}$ as substrates.

The rate of UTP labeling from $\left[{ }^{3} \mathrm{H}\right]$ uridine (uridine kinase activity) in $\mathrm{PC}$ retinal high-speed supernatants did not differ from that seen in $\mathrm{N}$ retinal preparations at 2 days PC. Thereafter, uridine kinase activity sharply increased, peaked by day 4 (about 35\% increased over $\mathrm{N}$ retina), and gradually returned to the normal retinal level by day 21 (Fig. $2, \mathrm{~A})$. At none of the times measured did the uridine kinase activity in the $\mathrm{N}$ retinas show significant deviations from levels seen in unoperated fish.

The changes in the rates of UTP labeling from $\left[{ }^{3} \mathrm{H}\right]$ UMP (UMP kinase activity) or from $\left[{ }^{3} \mathrm{H}\right]$ UDP (UDP kinase activity) in the PC retinas showed patterns quite similar to the change in uridine kinase activity during optic nerve regeneration (Fig. 2, B and C). The maximal enhancements in the UMP and UDP kinase activities were also seen at 4 days PC, and the percent stimulations over normal retina were about $35 \%$. The $\mathrm{N}$ retinas showed no significant variations in the activities of UMP or UDP kinase at any of the times examined.

\section{Activities of Lactic Dehydrogenase and Pyruvate Kinase in the Retina After Optic Nerve Crush}

The apparent coordinate activation of three separate enzymes involved in nucleoside and nucleotide metabolism raised the question as to whether these results reflect a generalized hypertrophic response of the retina to optic nerve crush. We therefore 


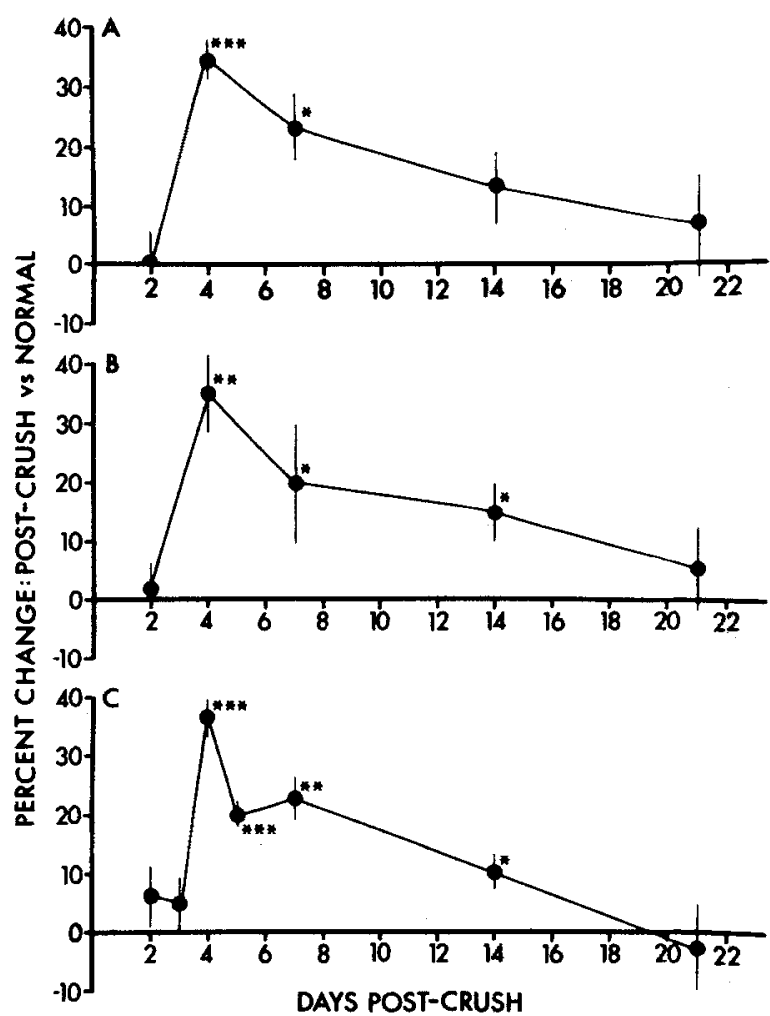

FIG. 2. Changes in the activities of retinal uridine kinase (A), UMP kinase (B), and UDP kinase (C) during optic nerve regeneration. Retinal high-speed supernatant fractions were prepared from three to tive groups of five pooled $\mathrm{N}$ or PC retinas at various times following optic nerve crush, and aliquots were incubated with $\left[{ }^{3} \mathrm{H}\right]$ uridine, $\left[{ }^{3} \mathrm{H}\right] \cup M P,\left[{ }^{3} \mathrm{H}\right]$ UDP as described in Materials and Methods. Enzyme activities were measured by the rate of conversion of each substrate to UTP. Results are expressed as the percent difference between $\mathrm{N}$ and $\mathrm{PC}$ retinal preparations. Vertical lines represent S.E.M. ${ }^{*} P<0.05 ;{ }^{* *} P$ $<0.01 ;{ }^{* * *} P<0.005$.

measured the activities of two cytosolic enzymes, $\mathrm{LDH}$ and $\mathrm{PK}$, in $\mathrm{N}$ and $\mathrm{PC}$ retinas at 4 and 8 days PC (Table 2). Neither enzyme activity in the PC retinas differed from that in the $\mathbf{N}$ retinas at either time point.

\section{Characterization of Enhanced UDP Kinase Activity in Post-Crush Retina}

Given the greater activity of UDP kinase relative to uridine kinase and UMP kinase, we used this

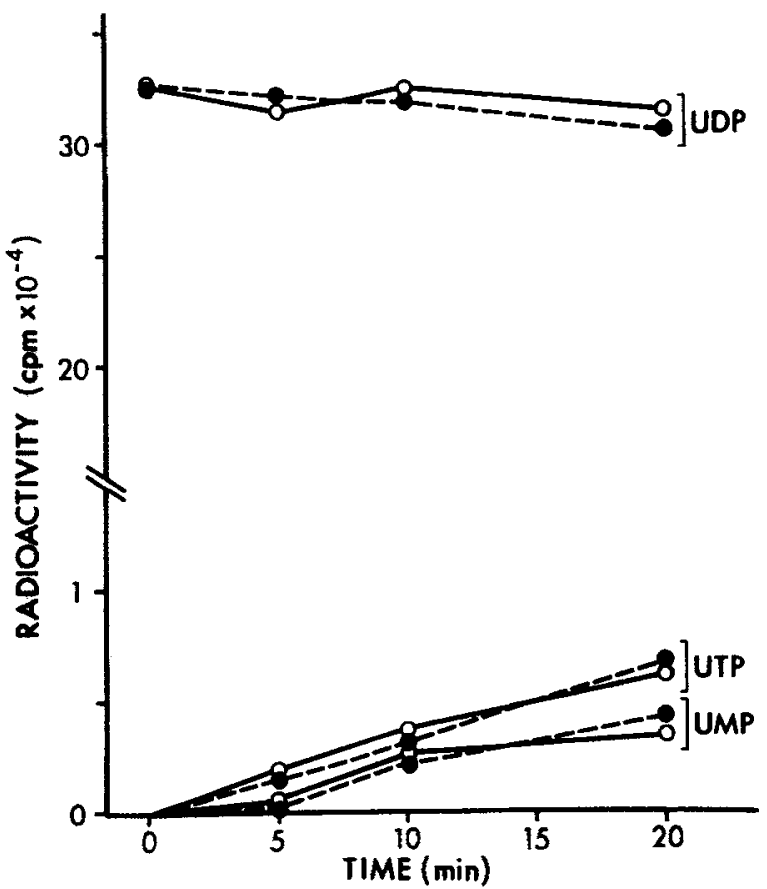

FIG. 3. Stability of $\left[{ }^{3} \mathrm{H}\right]$ UDP in retinal incubations in the absence of ATP. Day $4 \mathrm{PC}$ and $\mathrm{N}$ retinal high-speed supernatant fractions obtained from 25 fish were dialyzed overnight against homogenization buffer and $100 \mu \mathrm{l}$ of each supernatant retentate was incubated with $1 \mu \mathrm{Ci}$ of $\left[{ }^{3} \mathrm{H}\right]$ UDP (final $10^{-3}$

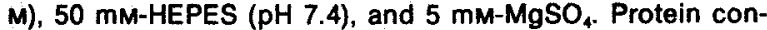
centrations in PC and $N$ retinal supernatants were $38 \mu \mathrm{g} / 100$ $\mu \mathrm{l}$ and $36 \mu \mathrm{g} / 100 \mu \mathrm{l}$, respectively. The radioactivity of UMP, UDP, and UTP was examined by HVE. Each point represents mean c.p.m./assay tube from duplicate assays. $\mathrm{O} \longrightarrow \mathrm{N}$ retina; -... PC retina.

enzyme to characterize in greater detail the nature of the enhancements seen during optic nerve regeneration. The differences observed in UDP kinase activity between the $P C$ and $N$ retinas could be explained by the following possibilities: (1) decreased phosphohydrolase activity in PC retinal preparations; (2) altered availability (e.g., decreased degradation or increased synthesis) of ATP in PC retinas; (3) altered endogenous substrate concentrations; (4) presence of an activator or inhibitor of UDP kinase or UTP phosphohydrolase in PC or N retinas; or (5) increased amount of enzyme in PC retinas compared with $\mathrm{N}$ retinas.

Mediation of the observed effect by a decrease in

TABLE 2. Activities of lactic dehydrogenase and pyruvate kinase in goldfish retina

\begin{tabular}{cccc}
\hline Days post-crush & Retina & Lactic dehydrogenase & Pyruvate kinase \\
\hline \multirow{2}{*}{ Day 4 } & N & $4.59 \pm 0.05$ & $1.21 \pm 0.05$ \\
& PC & $4.63 \pm 0.07$ & $1.19 \pm 0.03$ \\
Day 8 & N & $4.76 \pm 0.22$ & $1.30 \pm 0.04$ \\
& PC & $4.74 \pm 0.19$ & $1.29 \pm 0.04$ \\
\hline
\end{tabular}

Each value represents mean \pm S.E.M. $\mu \mathrm{mol} / \mathrm{mg}$ protein/min obtained from five groups of five pooled $\mathrm{N}$ and $\mathrm{PC}$ retinas. 
TABLE 3. Effect of pre-incubation on UDP kinase activity in goldfish retina

\begin{tabular}{cccc}
\hline Retina & Pre-incubation & $\begin{array}{c}\text { UDP kinase activity } \\
\left.\text { (d.p.m. } \times 10^{-5} / \mathrm{mg} \text { protein } / \mathrm{min}\right)\end{array}$ & $\begin{array}{c}\text { \% Difference } \\
(\mathbf{P C}-\mathbf{N} / \mathbf{N} \times 100)\end{array}$ \\
\hline N & $5 \mathrm{~min}$ & $8.78 \pm 0.13$ & 28 \\
PC & $5 \mathrm{~min}$ & $11.3 \pm 0.50$ & 27 \\
N & $20 \mathrm{~min}$ & $8.88 \pm 0.15$ & 27 \\
PC & $20 \mathrm{~min}$ & $11.3 \pm 0.40$ & \\
\hline
\end{tabular}

An aliquot of high-speed supernatant fractions prepared from day $4 \mathrm{PC}$ or $\mathrm{N}$ retinas was preincubated for 5 or 20 min with assay medium containing $50 \mathrm{~mm}$-HEPES, pH 7.4, 0.2 mM-ATP, $0.5 \mathrm{mM}-\mathrm{PGA}$, and $5 \mathrm{mM}-\mathrm{MgCl}_{2}$. The reaction was then initiated by the addition of $1.0 \mu \mathrm{Ci}$ of $\left[{ }^{3} \mathrm{H}\right] \mathrm{UDP}\left(10^{-3} \mathrm{M}\right)$ and $5 \mathrm{~min}$ later, was terminated by the addition of $10 \%$ TCA. UTP labeling was determined $t$. HVE. Each value is the mean \pm S.E.M. obtained from three groups of five $N$ and PC pooled retinas. The PC - N differences in both pre-incubation experiments are statistically significant $(P<0.01)$.

pyrophosphohydrolase activity in PC retinal extracts appears ruled out by an experiment in which labeled UDP was incubated with retinal extracts in the absence of ATP and PGA. Minimal breakdown was seen, and there was no difference between activities of PC and N preparations (Fig. 3). Minor amounts of UTP and UMP formed were the apparent products of UDP dismutation, e.g., by myokinase. To establish whether a specific UTP phosphohydrolase was present, $\left[{ }^{3} \mathrm{H}\right] \mathrm{UDP}$ was preincubated with either $P C$ or $N$ retinal extracts in the presence of ATP, PGA, and $\mathrm{Mg}^{2+}$ and then incubated further in the presence of $2 \times 10^{-2} \mathrm{M}$ EDTA. Addition of the chelating agent lowered the kinase activities of $\mathrm{PC}$ and $\mathrm{N}$ extract incubations $68 \%$ and $73 \%$, respectively. Had UTP hydrolysis been responsible for the enhancement of labeling seen in PC retinal extracts, the inhibitory effect of EDTA should have been much greater in the $\mathrm{N}$ preparation. It was therefore concluded that nucleotide phosphohydrolase activities did not play a significant role in the observed effect.

In order to examine the second possibility, an assay medium containing ATP and PGA (see Materials and Methods) was preincubated with day 4 PC or $\mathrm{N}$ retinal preparations for 5 or $20 \mathrm{~min}$, and UDP kinase was subsequently measured by the addition of $\left[{ }^{3} \mathrm{H}\right]$ UDP (Table 3). After a 5- or 20-min preincubation the usual stimulation was observed in the PC retina compared with $\mathrm{N}$ retina, suggesting that degradation or synthesis of ATP in the preparations did not account for the observed differences in UDP kinase activity between $\mathrm{PC}$ and $\mathrm{N}$ retinas.

Table 4 shows UDP kinase activity obtained in dialyzed high-speed supernatant fractions obtained from $\mathrm{PC}$ and $\mathrm{N}$ retinas removed on day $4 \mathrm{PC}$. While the UDP kinase activity was more variable in each of three separate experiments than was observed in nondialyzed preparations, about the same magnitude of stimulation was observed in PC compared with $\mathrm{N}$ retinal preparations (Fig. 2, C), ruling out the possibility that a difference in endogenous substrate concentrations between $\mathrm{N}$ and $\mathrm{PC}$ retinal supernatant fractions could account for the observed stimulation.

To examine the possible existence of an inhibitor or activator in either the PC or N retina, the highspeed supernatant fractions prepared from day $4 \mathrm{PC}$ and $\mathrm{N}$ retina were mixed (1:1) and UDP kinase activity was measured. A mixture of day $4 \mathrm{PC}$ and $\mathrm{N}$

TABLE 4. UDP kinase activity in dialyzed retinal high-speed supernatants

\begin{tabular}{lcc}
\hline Enzyme preparation & $\begin{array}{c}\text { UDP kinase activity } \\
\left.\text { (d.p.m. } \times 10^{-5} / \mathrm{mg} \text { protein } / \mathrm{min}\right)\end{array}$ & $\begin{array}{c}\% \text { Difference } \\
(\mathrm{PC}-\mathrm{N} / \mathrm{N} \times 100)\end{array}$ \\
\hline Experiment I & 8.98 & 25 \\
N & 11.2 & \\
PC & & 32 \\
Experiment II & 7.58 & \\
N & 10.0 & 35 \\
PC & & \\
Experiment III & 13.0 & \\
N & 17.6 & \\
PC &
\end{tabular}

Day $4 \mathrm{PC}$ and $\mathrm{N}$ high-speed supernatant fractions obtained from 25 retinas were dialyzed overnight against homogenization buffer and assayed with $\left[{ }^{3} \mathrm{H}\right]$ UDP as described in Materials and Methods. UTP labeling was examined by HVE. Each value is the mean d.p.m./mg protein/min from duplicate or triplicate assays of each preparation. 


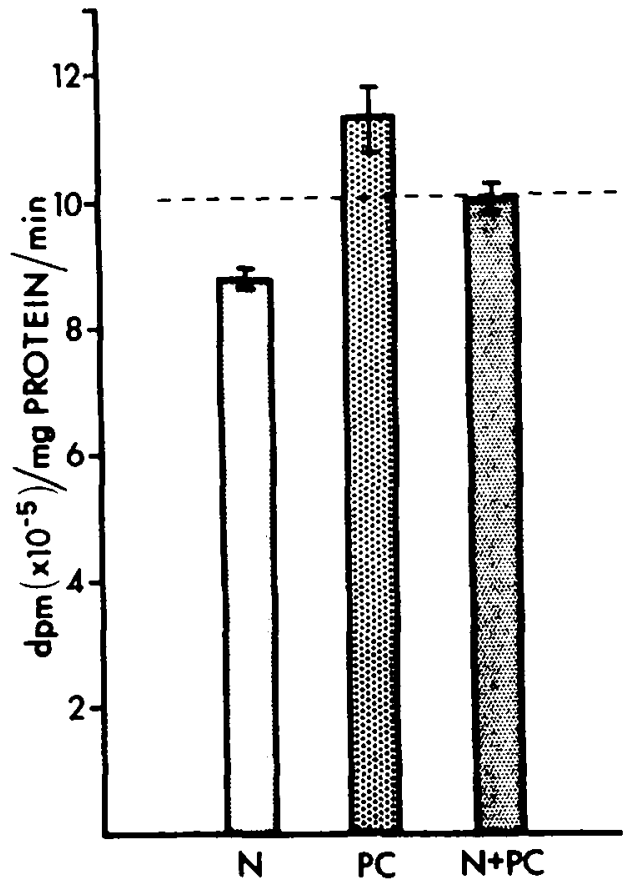

FIG. 4. Characterization of enhanced UDP kinase activities in day $4 \mathrm{PC}$ and $\mathrm{N}$ retinas. High-speed supernatant fractions were prepared from day $4 P C$ and $N$ retinas. Equal volumes of each sample were mixed where indicated. Each column is the average d.p.m./mg protein $/ \mathrm{min} \pm$ S.E.M. obtained in UTP from three groups of five $P C$ and $N$ retinas. The dotted line represents the predicted value from the numerical average of $P C$ and $N$ preparations.

retinal high-speed supernatant fractions possessed UDP kinase activity comparable to the numerical average of the activity of such enzyme preparations (Fig. 4). The $K_{m}$ values of UDP kinase for UDP were also examined, using dialyzed retinal highspeed supernatant fractions prepared from day $4 \mathrm{PC}$ and $\mathrm{N}$ retinas. As shown in Fig. 5 , the $K_{\mathrm{m}}$ values for UDP in PC retinas did not differ from that in N retinas $\left(K_{\mathrm{m}}=8.6 \times 10^{-5} \mathrm{M}\right)$.

The results, therefore, suggest that the amount of kinase is increased in the PC retinas following optic nerve axotomy. This conclusion is supported by the fact that the incremental activity of UDP kinase observed in day $4 \mathrm{PC}$ retina was abolished by the prior intraocular injection of actinomycin D (0.1 and 0.5 $\mu \mathrm{g} / \mathrm{eye}$ ), an inhibitor of RNA synthesis (Table 5).

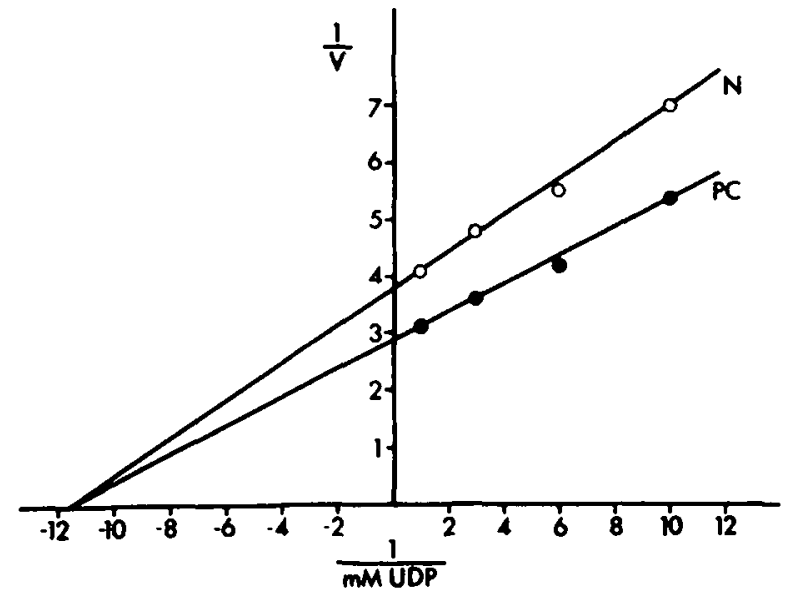

FIG. 5. Kinetics of UDP kinase activities. Day $4 P C$ and $N$ retinal high-speed supernatant fractions were dialyzed overnight against homogenization buffer. An aliquot of each preparation was incubated for 1-2 min with $1.0 \mu \mathrm{Ci}$ of [ ${ }^{3} \mathrm{H}$ ]UDP at final concentrations of 0.1-1.0 mM. The concentrations of ATP, PGA, and $\mathrm{MgCl}_{2}$ were held constant at 0.2 $\mathrm{mM}, 0.5 \mathrm{mM}$, and $5 \mathrm{mM}$, respectively. UDP kinase activity was measured as described in Materials and Methods.

\section{DISCUSSION}

A number of biochemical consequences in the retina that follow crush of its optic nerve have been reported, including increase in poly(A)-RNA (Burrell et al., 1978) and tubulin labeling (Heacock and Agranoff, 1976), as well as in tubulin mRNA (Burrell et al., 1979). An increase in the utilization of uridine by $P C$ retina incubated in the presence of the labeled nucleoside was inferred to be the consequence of increased phosphorylation of uridine and its nucleotides (Dokas et al., 1981). In the present study, we investigated further the nature of this increase, using cell-free preparations of $\mathrm{PC}$ and $\mathrm{N}$ goldfish retina.

High-speed supernatant fractions of retinal homogenates are shown to phosphorylate labeled uridine, UMP, and UDP in the presence of added ATP. In contrast to the whole retinal studies (Dokas et al., 1981), in which the intermediate nucleotides UMP and UDP, as well as UDP sugar accumulate, labeled UTP is the major product in cell-free preparations (Fig. 1). The labeling pattern in the extracts is a consequence of the activities of the various

TABLE 5. Effect of actinomycin D on UDP kinase activity in goldfish retina

\begin{tabular}{cccc}
\hline Actinomycin D & Enzyme preparation & $\begin{array}{c}\text { UDP kinase activity } \\
\text { (d.p.m. } \times 10^{-5} / \mathrm{mg} \text { protein/min) }\end{array}$ & $\begin{array}{c}\text { \% Difference } \\
(\mathrm{PC}-\mathrm{N} / \mathrm{N} \times 100)\end{array}$ \\
\hline \multirow{2}{*}{$0.1 \mu \mathrm{g}$} & N & $9.60 \pm 0.24$ & +8.1 \\
& PC & $10.4 \pm 0.27$ & -4.5 \\
\hline & N & $10.2 \pm 0.10$ & \\
\hline
\end{tabular}

Each value is the mean \pm S.E.M. of three groups of tive pooled $\mathrm{N}$ or $\mathrm{PC}$ retinas. Actinomycin $\mathrm{D}$ $(0.1 \mu \mathrm{g}$ or $0.5 \mu \mathrm{g} / \mathrm{eye}$ ) was injected into both eyes at 2 and 3 days PC. Retinal high-speed supernatants were obtained at 4 days. UDP kinase activity was measured as described in Materials and Methods. 
kinases as shown in Table 1. The pattern seen in whole tissue (Dokas et al., 1981) may reflect intracellular compartmentation, ATP availability, or the selective loss of uridine kinase activity on homogenization. The lability of uridine kinase following homogenization has been reported in other instances (Krystal and Scholefield, 1973; ValentinHansen, 1978).

While labeled uridine is frequently used for studies on nucleotide metabolism because of its ready entry into intact cells, it must be borne in mind that its phosphorylation is part of the so-called salvage pathway, whose importance relative to the de novo pyrimidine pathway must be considered (Mandel, 1971; Levine et al., 1974). Activation of uridine metabolism has been studied extensively in cell culture systems. Intact $\mathrm{GH}_{4} \mathrm{C}_{1}$ cells respond to added thryotropin-releasing hormone (TRH) with enhanced phosphorylation of added uridine. However, if the cells are disrupted following exposure to TRH, they no longer exhibit the increased rate of phosphorylation (Martin and Tashjian, 1978). Likewise, Goldenberg and Stein (1978) have demonstrated that enhanced uridine phosphorylation in serum-stimulated 3T3 cells is lost on homogenization. These results suggest that the enhancement is mediated by an anisotropic membrane mechanism. In the present experiments, uridine kinase activities may be diminished, but a difference between PC and $\mathrm{N}$ retinas (about $35 \%$ at 4 days $\mathrm{PC}$ ) in the highspeed supernatant fraction remains (Fig. 2, A). The activities of UMP kinase and UDP kinase increase in $\mathrm{PC}$ compared with $\mathrm{N}$ retinas in the same temporal pattern as observed for uridine kinase activity. The coordinate activation of three separate enzymes involved in nucleotide metabolism raised the question as to whether these results reflect a relatively nonspecific hypertrophic response of the retina following axotomy. Kaye et al. (1978) reported an increase in acid phosphatase activity in the rat nodose ganglia following unilateral cervical vagotomy, and reports of enhanced utilization of $\left.{ }^{14} \mathrm{C}\right]-2$-deoxyglucose (Singer and Mahler, 1979; Agranoff et al., 1980) and in protein synthesis (Agranoff et al., 1980) following axotomy of the rat hypoglossal nerve support this possibility. There is evidence, on the other hand, that the changes that occur in cell bodies following axotomy are selective. For example, although there is some increase in protein synthesis, tubulin labeling appears to be selectively enhanced (Heacock and Agranoff, 1976; Giulian et al., 1980). Also, the fact that the activities of at least two enzymes, LDH and PK, are not altered as a result of crush (Table 2) suggests some degree of specificity of the kinase enhancements seen in the present study.

While uridine kinase is specific to the salvage pathway, UMP and UDP kinase also subserve the de novo pathway. Preliminary studies with $\left[{ }^{3} \mathrm{H}\right]$ orot- ic acid incubated with retinal extracts in the presence of pyrophosphoryl-ribose phosphate (PRPP) indicate a $30 \%$ stimulation of its conversion to nucleotides following optic nerve crush, suggesting that de novo pyrimidine synthesis is enhanced as well as the salvage pathway. Of possible relevance is the finding of Kaye et al. (1978) that following unilateral cervical vagotomy in the rat, there is an increase in activity of glutamine-dependent carbamoyl phosphate synthetase, a key enzyme in pyrimidine biosynthesis. The increase, however, is seen in both axotomized and contralateral "control" ganglia. This enzyme has not yet been investigated in the goldfish system, although we recently found a generalized increase in ornithine decarboxylase following nerve crush. The increase is found in both PC and $\mathrm{N}$ retinas as well as in the brain and kidney compared with unoperated control fish (Kohsaka et al., 1981). The maximum increase in ornithine decarboxylase (about two to three-fold that seen in unoperated fish) occurs at day $5 \mathrm{PC}$, in contrast to the unilateral nucleoside and nucleotide kinase effects, which are maximal on day 4 PC. While polyamines have been implicated in nucleic acid and protein synthesis, we presently speculate that the increase in ornithine decarboxylase is mediated by a humoral mechanism and may be related to the degenerating optic nerve stump as well as to the ganglion cell response to crush (Kohsaka et al., 1981).

The present studies have characterized the nature of the increase in uridine metabolism that occurs in the retina during optic nerve regeneration. The absence of altered hydrolytic activity (Fig. 3) indicates the increased labeling involves kinase activities. Pre-incubation with ATP (Table 3) and studies with dialyzed preparations (Table 4) rule out the possibility that substrate dilution was responsible for the observed effects. Experiments in which PC and N retinal preparations were mixed (Fig. 4) are interpreted to indicate that $\mathrm{PC}$ retina contains more active enzyme than $\mathrm{N}$ retina. Preliminary investigations had suggested that the mixture of PC and $\mathrm{N}$ retinas gave rise to activities less than the mean, indicating the presence in normal retinas of an inhibitory factor (Dokas and Agranoff, 1979). Extensive re-investigation of the paradigm did not confirm the earlier finding, and it is concluded on the basis of present findings that there is no support for the existence of the putative inhibitory factor in normal retinas.

Because of its greater activity, UDP kinase activity was used as a model system for the effect. Whereas UMP kinase is reported to be specific for the uridine nucleotides (Anderson, 1973), phosphorylation of UDP is generally attributed to an enzyme that catalyzes transfer of the $\gamma$ phosphorus of ATP to a number of nucleoside diphosphate (NDP) acceptors (Agarwal and Parks, 1971). In the present 
studies, the $K_{\mathrm{m}}$ for UDP was unaltered between PC and $\mathrm{N}$ retinas (Fig. S) and the enhancement was abolished by injection on days 2 and 3 of actinomycin D (Table 5). The results suggest that the enhanced NDP kinase activity in the preparation reflects increased synthesis of the enzyme following optic nerve crush. Since a time course of increase in tubulin synthesis (Heacock and Agranoff, 1976) appears to correlate with that of the kinases, it is of interest that NDP kinase has been identified as a tubulin-associated protein (Watanabe and Flavin, 1976; Nickerson and Wells, 1978). Furthermore, NDP kinase is believed to play a role in the regulation of microtubular assembly (MacNeal and Purich, 1978; Terry and Purich, 1979).

Although ganglion cells represent only about $5 \%$ of the total retinal mass (Murray and Grafstein, 1969), that they are the principal site of the observed biochemical alterations is supported by histological studies (Murray and Grafstein, 1969; Murray, 1973; Grafstein and McQuarrie, 1978). Assuming that the nucleoside and nucleotide kinase enhancements are mediated purely by the ganglion cells, one can then calculate that a $35 \%$ stimulation actually represents an eight-fold increase in the enzymes in the relevant cell bodies.

The delay between injury and detectable biochemical alterations in the ganglion cells may yield information regarding the nature of the biological message that mediates the enhancement. One possibility is that a growth-retarding substance that normally reaches the retina by retrograde axonal flow from synaptic terminals maintains a negative feedback control on retinal metabolism (Lynch and Cotman, 1975; Cotman and Nadler, 1978). Disruption of supply of the putative agent via retrograde flow would then result in activation of the perikaryon. Eventual return of nucleoside and nucleotide kinase activity to normal levels may be related to the time that regenerated fibers reach the tectum and reestablish normal presynaptic physiology (Murray, 1976; Springer and Agranoff, 1977). Biochemical "handles" such as have been established in the present preparation may serve to further study this question, and more generally, to elucidate mechanisms of nerve regeneration.

\section{ACKNOWLEDGMENTS}

The work was supported by NIMH grant NS 13743 and 12506. S.K. was supported by the Fukuzawa Memorial Grant of Keio University, Tokyo, Japan, and L.A.D. was supported by NIMH Interdisciplinary Training Grant MH 013831. The authors thank Ms. Marianne Andrews for technical assistance.

\section{REFERENCES}

Agarwal R. P. and Parks R. E. Jr. (1971) Erythrocytic nucleoside diphosphokinase. J. Biol. Chem. 246, 2258-2264.
Agranoff B. W., Smith C. B., and Sokoloff L. (1980) Regional protein synthesis in rat brain afler hypoglossal axotomy. Trans. Am. Soc. Neurochem. 11(1), 95.

Anderson E. P. (1973) Nucleoside and nucleotide kinases, in The Enzymes, 3rd ed. (Boyer P. D., ed), pp. 49-96. Academic Press, New York.

Bandurski R. S. and Axelrod B. (1951) The chromatographic identification of some biologically important phosphate esters. J. Biol. Chem. 193, 405-410.

Burrell H. R., Dokas L. A., and Agranoff B. W. (1978) RNA metabolism in the goldfish retina during optic nerve regeneration. J. Neurochem. 31, 289-298.

Burrell H. R., Heacock A. M., Water R. D., and Agranoff B. W. (1979) Increased tubulin messenger RNA in the goldfish retina during optic nerve regeneration. Brain Res. 168, $628-632$.

Cotman C. W. and Nadler J. V. (1978) Reactive synaptogenesis in the hippocampus, in Neuronal Plasticity (Cotman C. W., ed), pp. 227-271. Raven Press, New York.

Cragg B. G. (1970) What is the signal for chromatolysis? Brain Res. 23, 1-21.

Dokas L. A. and Agranoff B. W. (1979) RNA precursor metabolism characterized during optic nerve regeneration. Trans. Am. Soc. Neurochem. 10(1), 232.

Dokas L. A., Kohsaka S., Burrell H. R., and Agranoff B. W. (1981) Uridine metabolism in the goldfish retina during optic nerve regeneration: Whole retina studies. $J$. Neurochem. $36,1160-1165$.

Dunlop D. S., Van Elder W., and Lajtha A. (1974) Measurement of rates of protein synthesis in rat brain slices. $J$. Neurochem. 22, 821-830.

Giulian D., Ruisseaux H. D., and Cowburn D. (1980) Biosynthesis and intra-axonal transport of proteins during neuronal regeneration. J. Biol. Chem. 255, 6494-6501.

Goldenberg G. J. and Stein W. D. (1978) Stimulation of uridine uptake in 3T3 cells is associated with increased ATP affinity of uridine-phosphorylating system. Nature 274, 475-477.

Grafstein B. and McQuarrie I. G. (1978) Role of the nerve cell body in axonal regeneration, in Neuronal Plasticity (Cotman C. W., ed), pp. 155-195. Raven Press, New York.

Heacock A. M. and Agranoff B. W. (1976) Enchanced labeling of a retinal protein during regeneration of optic nerve in goldfish. Proc. Natl. Acad. Sci. USA 73, 828-832.

Ingoglia N. A. (1978) The effect of intraocular injection of cordycepin on retinal RNA synthesis and on RNA axonally transported during regeneration of the optic nerves of goldfish. J. Neurochem. 30, 1029-1039.

Kaye P. L., Jeffrey R. L., and Austin L. (1978) Bilateral enzymic changes in rat nodose ganglia following unilateral cervical vagotomy. Neuroscience 3, 1231-1239.

Kohsaka S., Schwartz M., and Agranoff B. W. (1981) Increased activity of ornithine decarboxylase in goldfish following optic nerve crush. Dev. Brain Res. (in press).

Krystal G. and Scholefield P. G. (1973) The partial purification and properties of uridine kinase from Ehrlich ascites tumor cells. Can. J. Biochem. 51, 379-389.

Levine R. L., Hogenraad N. J., and Kretchmer N. (1974) A review: Biological and clinical aspects of pyrimidine metabolism. Pediatr. Res. 8, 724-734.

Lowry O. H., Rosebrough N. J., Farr A. L., and Randall R. J. (1951) Protein measurement with the Folin phenol reagent. J. Biol. Chem. 193, 265-275.

Lynch G. and Cotman C. W. (1975) The hippocampus as a model for studying anatomical plasticity in the adult brain, in The Hippocampus Vol. I: Structure and Development (Isaacson R. L., and Pribam K. H., eds), pp. 123-154. Plenum Press, New York.

MacNeal R. K. and Purich D. L. (1978) Stoichiometry and role of GTP hydrolysis in bovine neurotubule assembly. J. Biol. Chem. 253, 4683-4687.

Mandel P. (1971) Free nucleotides, in Handbook of Neurochemistry (Lajtha A., ed), pp. 249-281. Plenum Press, New York. 
Martin T. J. F. and Tashjian A. H. (1978) Thyrotropin-releasing hormone modulation of uridine uptake in rat pituitary cells. Evidence that uridine phosphorylation is regulated. J. Biol. Chem. 253, 106-115.

Murray M. (1973) ${ }^{3} \mathrm{H}$-Uridine incorporation by regenerating retinal ganglion cells of goldfish. Exp. Neurol. 39, 489-497.

Murray M. (1976) Regeneration of retinal axons into the goldfish optic tectum. J. Comp. Neurol. 168, 175-196.

Murray M. and Grafstein B. (1969) Change in the morphology and amino acid incorporation of regenerating goldfish optic neurons. Exp. Neurol. 23, 544-560.

Nicholas P. C. and Bachelard H. S. (1974) Kinetic properties of cerebral pyruvate kinase. Biochem. J. 141, 165-171.

Nickerson J. A. and Wells W. W. (1978) Association of nucleoside diphosphate kinase with microtubules. Biochem. Biophys. Res. Commun. 85, 820-826.

Singer P. A. and Mahler S. (1979) The time course of increased glucose utilization in hypoglossal nucleus neurons during regeneration. Soc. Neurosci. 5, 683 (Abstr.).

Springer A. D. and Agranoff B. W. (1977) Effect of temperature on rate of goldfish optic nerve regeneration: A radioautographic and behavioral study. Brain Res. 128, 405-415.

Terry B. J. and Purich D. L. (1979) Nucleotide release from tubulin and nucleoside $5^{\prime}$-diphosphate kinase action in microtubule assembly. J. Biol. Chem. 254, 9469-9476.

Valentin-Hansen P. (1978) Uridine-cytidine kinase from $E_{s}$ cherichia coli, in Methods in Enzymology, Vol. LI (Hoffee P. A. and Jones M. E., eds), pp. 308-314. Academic Press, New York.

Watanabe T. and Flavin M. (1976) Nucleotide-metabolizing enzymes in chlamydonas flagella. J. Biol. Chem. 251, $182-192$.

Wroblewski F. and LaDue J. S. (1955) Lactic dehydrogenase activity in blood. Proc. Soc. Exp. Biol. Med. 90, 210-213. 